\title{
Uptake in action
}

Book or Report Section

Accepted Version

De Gaynesford, M. (2017) Uptake in action. In: Tsohatzidis, S. (ed.) Interpreting J.L. Austin: critical essays. Cambridge University Press, Cambridge. doi: https://doi.org/10.1017/9781316421840.005 Available at https://centaur.reading.ac.uk/65785/

It is advisable to refer to the publisher's version if you intend to cite from the work. See Guidance on citing.

To link to this article DOI: http://dx.doi.org/10.1017/9781316421840.005

Publisher: Cambridge University Press

All outputs in CentAUR are protected by Intellectual Property Rights law, including copyright law. Copyright and IPR is retained by the creators or other copyright holders. Terms and conditions for use of this material are defined in the End User Agreement.

\section{www.reading.ac.uk/centaur}

\section{CentAUR}

Central Archive at the University of Reading

Reading's research outputs online 


\section{UPTAKE IN ACTION}

Maximilian de Gaynesford

\section{The Austinian Analysis}

In an influential series of articles, Rae Langton has argued that some speakers are rendered incapable of performing the illocutionary acts they try to perform and are thus, in a particular way, silenced. ${ }^{1}$ I shall first meet recent strong objections to the general analysis underlying this argument, then raise a significant new problem, revise the analysis accordingly, and finally demonstrate its usefulness.

Langton explains her thesis by appeal to J. L. Austin, who claimed that if a speaker is to perform an illocutionary act, she must secure the 'uptake' of her audience, where this means grasping the illocutionary force of her utterance (Austin, 1975 116-7). In Austin's own favoured example, to warn an audience requires getting it to recognise one is issuing a warning. Suppose that circumstances conspire against taking a speaker or her utterances seriously. One manifestation of this may be that she fails to secure her audience's uptake. Suppose she tries to warn an audience, saying 'There is a wolf coming!' but they think she is merely joking, or seeking attention. Because they do not take her utterance seriously, they may not understand that she is indeed issuing a warning. If Austin is right and uptake is indeed a necessary condition on performing illocutionary acts, then this speaker is unable to perform - better, perhaps, rendered incapable of performing - the illocutionary act she tries to perform. And given this configuration of circumstances, we may thus regard her as silenced. ${ }^{2}$

Because this one particular analysis of one particular sort of silencing turns on appeal to Austin's claim about uptake, we may call it the 'Austinian

${ }^{1}$ Originally appearing from 1990 onwards, and developing ideas of Catharine MacKinnon (1987, pp. 163-197), the relevant papers have since been revised and collected in her (2009; see in particular essays 1-8). Jennifer Hornsby formulated arguments to the same conclusion at the same time but by revising Austin's account of illocutionary acts and doing so, at least initially, without appeal to his notion of 'uptake' (see in particular her 1994), so her versions are not the focus here.

${ }^{2}$ That this need not be a bad thing is under-recognised. Where peoples' attempts at illocutionary acts would, if successful, subordinate others, there is reason to cultivate an environment in which those acts could not successfully be performed (see de Gaynesford 2009a). This might be particularly relevant to situations involving hate speech, though discussions of the issue (e.g. Waldron 2012) tend to ignore the possibility. 
Analysis' (AA). ${ }^{3}$ Its components are these: there is a particular form of silencing in which: (a) speakers are taken as non-serious by their audience, and thus (b) fail to secure their audience's uptake, where (c) uptake is a necessary condition on performing illocutionary acts, so that $(\mathrm{d})$ they are unable to perform the illocutionary acts they try to perform, and thus (e) should be considered as silenced.

It is rare and exciting that so seemingly diminutive an aspect of philosophy of language (i.e. (c)) should grow into so general an analysis, with a conclusion (i.e. (e)) that has such deep implications for our lives, across so broad a range of institutions: social, legal, political. But AA has recently come under strong attack. ${ }^{4}$ Miranda Fricker has argued that it is less empirically likely than her alternative analyses of silencing because it requires the erosion of a speaker's human and epistemic status. (Fricker 2007, Ch. 6, esp. pp. 13742). Ishani Maitra has claimed that it does not offer an analysis of illocutionary silencing because, for all the analysis shows, it is actually perlocutionary acts that disadvantaged speakers are unable to perform (Maitra 2009). And Nancy Bauer has argued that it misses the point; to focus on failure of uptake is to ignore the real issue, which is the absence of human exchange (Bauer 2015 Chs 5-6, esp. pp 83, 99).

These objections fail in their own aims, I shall argue (II). But they do support what we have independent reason to perform: a revision of AA, by correcting the claim about uptake (III). And the upshot is positive, because revised AA gives fresh insight into the phenomena of silencing, a claim I shall demonstrate for a particularly notorious and complex case: Austin's remarks on poetry (IV).

\section{Objections and Replies}

For reasons that will become clear, it is necessary to describe each of the three objections first, before responding to them.

Miranda Fricker argues that AA requires a conception of silencing that is less 'empirically likely' than the alternative she favours (Fricker 2007, p. 141). The objection seems mild enough; it does not insist or require that AA be somehow contradictory or reliant on false premises. But set against Fricker's

${ }^{3}$ The label is doubly apt if Martin Gustafsson is right, that debate over this issue stands out as one where 'participants actually read and discuss what Austin says' (Gustafsson 2011, p. 18).

${ }^{4}$ Most objections to Langton focus on the application of this analysis - to the pornography debate (e.g. Saul 2006, pp. 229-48; Mikkola 2008, pp. 316-20), but my focus is on the analysis itself. Many other objections to Langton focus on a different argument altogether: that pornography subordinates women (see my 2009a, which sharply distinguishes the two; also Maitra 2012 pp. 95-118).

These too I set aside to remain focused on the silencing issue. 
careful delineation of alternative conceptions of silencing, it is particularly telling (Fricker 2007, Ch 6). Her contention is that, on AA, the silencing in question would be 'purely communicative', a failure of that 'reciprocity' between speaker and audience which communication calls for and which is required for the audience's uptake (Fricker 2007, p. 140). ${ }^{5}$ Whereas on her alternative 'epistemic model', this silencing would be based on a failure of credibility (Fricker 2007, p. 140). In effect, and with reference to the basic components of AA, this allows Fricker to move from (a) to (e) whilst bypassing (b)-(d). In cases where speakers are not taken seriously by their audience (i.e. (a)), what accounts for the fact that they are silenced (i.e. (e)) is that they are (wrongfully) excluded from the community of knowing, trusted informants, either because they are simply not asked for information, or because they are treated as mere sources of information (as something unminded might be treated).

Fricker then compares the two conceptions in terms of what each requires 'before the silencing effect kicks in' (Fricker 2007, p. 142). AA requires a failure of reciprocity, which would be prior to and more basic than what her conception requires: a failure of credibility. Indeed, so Fricker thinks, AA would involve a considerable erosion of the speaker's 'human status' (Fricker 2007, p. 142), whereas her conception would involve a much less extreme (but still potentially wrongful) depletion of confidence in the speaker. It is the difference between denying the speaker epistemic status altogether, and undervaluing that status. And because undervaluing (depletion of confidence) is 'the more empirically likely possibility', in Fricker's view (Fricker 2007, pp.141), she advances her conception as preferable.

Ishani Maitra argues that AA requires what it cannot provide: 'a criterion that successfully distinguishes illocutionary from perlocutionary acts' (2009, p. 318). Without such a criterion, she thinks, AA cannot assert that it is a specifically illocutionary act that a speaker is unable to perform in the silencing in question. And she contends that we lack such a criterion; neither Austin nor his successors have provided one. ${ }^{6}$ In effect, and with reference to

${ }^{5}$ Fricker appeals explicitly to the semi-technical notion of 'reciprocity' (2007 p. 140), introduced and developed by Hornsby as a way of distinguishing the illocutionary from the locutionary and perlocutionary (see in particular Hornsby 1994). There is perhaps a connection with Simone de Beauvoir's The Second Sex, in whose arguments the notion of reciprocity plays a key positive role.

${ }^{6}$ Austin himself was unhappy with the criteria he provides (1975 109-32). Hornsby supplies her own criteria, by appeal to the notion of reciprocity (1994 192-5). But Maitra denies that reciprocity does the work needed (2009 309-38). 
AA, this allows Maitra to accept (a) and perhaps (b), but to deny (c) and what follows. For all AA can show, she thinks, what speakers who are not taken seriously by their audience (i.e. (a)) are unable to perform is perlocutionary acts. This might or might not be a significant harm, but it would not be describable as silencing.

So consider examples of lesser and greater harms. ${ }^{7}$ Suppose I say 'There is a wasp by your ear', and you grasp that I am issuing a warning, but decide not to do any of the things that this warning was meant to encourage you to do, because you think me timid. You do not take me seriously and thus block my attempted perlocutionary acts, and that may do me mild harm ignoring my warning is a way of showing that you hold me in some mild disrespect-but we would not describe this as a situation where you silence me. Or consider a more serious harm: suppose I say 'I do not want to go on this dangerous fairground ride with you' and you grasp that I am issuing a refusal but decide not to do any of the things this refusal was meant to direct you to do, to leave me alone, and instead bundle me into the ride regardless. Here there is a significant harm, involving perhaps some physical and much psychological damage. But again, we would not describe your behaviour towards me-in not taking me seriously and thus blocking my attempted perlocutionary acts - as a form of silencing.

In short, if AA cannot distinguish an appeal to the illocutionary from an appeal to the perlocutionary, it fails to discriminate and understand this (or indeed any) form of silencing. So Maitra offers an alternative conception: the silencing in question is a matter of communicative disablement, which she elucidates by appeal to a Gricean communication intention theory, thus bypassing Austin's appeal to illocutionary acts.

Nancy Bauer argues that AA requires the audience's uptake to play a stronger role than it could, and a more significant role than it should. ${ }^{8}$ She think its role would have to be very strong because AA regards securing the audience's uptake as not only necessary for the speaker, if she is to perform an illocutionary act, but also sufficient for her performing that act (Bauer 2015, p. 99). ${ }^{9}$ And she thinks its role would have to be very significant because AA identifies what goes wrong in these kinds of silencing case with the failure to secure the audience's uptake. Bauer then contests both claims. In effect, and

\footnotetext{
7 These are my examples, designed to make Maitra's claims more salient. ${ }^{8}$ Bauer has several other arguments in play: some of them are about the issue of subordination rather than silencing; others are essentially about scholarship (whether AA captures what Austin says or means to commit himself to). I set these to one side here, so as to concentrate on the silencing issue.

${ }^{9}$ I shall not pursue the issue here, but this is not a defensible version of the uptake claim, and I see no grounds for believing Austin held it.
} 
with reference to AA, this enables her to accept (a) and perhaps (b) but to regard (b) as essentially irrelevant to (e) and to reject (c) altogether. Because AA gives too strong and significant a role to uptake, it fails to discriminate and understand the kind of silencing at issue, misidentifies what really calls for our attention, and hence fails to be an effective analysis.

Bauer argues that uptake cannot play so strong a role because "sometimes "uptake" is beside the point when it comes to the question of whether a certain act has been performed' (Bauer 2015, p. 99). She offers this example: suppose a woman orders a cup of coffee in a coffee shop and the waiter brings her a dry-measure cup of beans. It would not be 'illuminating', Bauer urges, to say that the woman failed to achieve uptake. And Bauer argues that uptake cannot play so significant a role because what goes wrong in the silencing cases at issue must actually be much deeper: it is 'the fact that there is not a human exchange going on here' which we need to appreciate, not whether or not there has been a failure of uptake (Bauer 2015, p. 83).

These three objections to AA are problematic but also insightful. I shall focus immediately on the problems, because we ought first to ask whether these objections oblige us to reject AA.

These objections are fundamentally at odds with each other. This is significant for various reasons, but particularly this: that if we ought to reject AA, it is not because they operate collectively to show this. If Fricker is right, then AA represents too communicative an analysis of the silencing in question, whereas if Maitra is right, then AA is not communicative enough. If Bauer is right, then AA adopts too anodyne an attitude to the silencing in question, thus misidentifying what is actually at stake (human exchange) with something superficial and insignificant, whereas if Fricker is right, then AA adopts too hyperbolic an attitude to the silencing in question, thus misidentifying what is at stake with something too deep and extreme (human status). If Bauer is right, we can reject AA without appeal to an alternative, whereas if Fricker and Maitra are right, rejection requires an alternative. Moreover these objections disagree fundamentally about what undermines AA. For Maitra, it is its appeal to illocution. For Bauer, it is its appeal to uptake. For Fricker, it is its appeal to reciprocity. So we cannot endorse any two of these objections together. If any of them show we ought to reject AA, it must do so individually and independently, and that is how we shall consider them.

Fricker's objection is that AA requires erosion of human and epistemic status, but about this she seems mistaken. AA might require such erosion if it portrayed the silencing effect as 'kicking in' before the question of the speaker's epistemic status could even arise for an audience, in such a way as to preclude its attributing such status to the speaker. And that is evidently what Fricker has in mind (Fricker 2007, pp. 140-2). But in fact AA is predicated on the audience's attributing epistemic status to the speaker, and 
in a particularly rich sense. What is potentially silencing about the situation in which the woman says 'there is a wolf coming', for example, is that her audience might be persuaded not to take her utterances seriously because they think she is merely joking or seeking attention. But this is not a situation that erodes the human status of the speaker, still less one that undermines her status as a knower. If anything, the silencing occurs because the audience treats the speaker as too knowing. They do not take her utterance seriously because they believe it is not meant seriously, and they do not believe it is meant seriously because they take her to be playing epistemic games with them. They suppose that she knows that they know that she knows that her utterances, which would in ordinary contexts count as performing warning actions, are in this context not to be taken as performing warning actions. ${ }^{10}$ To appreciate (a), that her utterance is not serious, the speaker and her audience have to be reciprocally 'in the know'. So AA works by, not against, attributing significant epistemic status to the speaker. This is a crucial feature of AA, and one that Fricker overlooks, undermining her objection.

Maitra's objection is that AA is unable to distinguish successfully in every case between illocutionary and perlocutionary acts. But it seems wrong to insist that AA needs a criterion that will do precisely that. Doubtless there are border issues and grey areas. But if uptake is necessary for illocutionary acts (and Maitra does not deny this), then all we have to show is that there is no uptake in order to conclude that - whatever else is happening - no illocutionary act can be taking place. And that is sufficient for AA to reach its conclusion, that the speaker is silenced. (A rough analogy: if I know hydrogen is necessary for water and that there is no hydrogen present, then I may know there is no water present-regardless of the fact that I may be quite unable to distinguish successfully in every case between hydrogen and oxygen.) Doubtless the border issues and grey areas mean that it is sometimes difficult or impossible to determine whether the speaker suffers perlocutionary disablement as well. And that may be a cause of further concern (of further injustice, perhaps). But AA has nothing to say about this further issue, and it need not: being able to point out illocutionary disablement is quite enough to identify a particular form of silencing.

${ }^{10}$ In applying AA to the pornography case, advocates similarly identify what is silencing with the audience's attribution of rich epistemic status to speakers. The reason why some men are said to assume that some women do not seriously mean 'no' when they say 'no' in response to a sexual invitation, is that, encouraged by pornography, they assume a particular kind of knowingness on the part of the woman: that she knows that they know that she knows she is only saying this as a fleeting pretence of modesty, or as a flirtatious device to excite desire. 
Bauer's objection is that uptake is often beside the point and that what goes wrong in silencing cases lies much deeper. But it seems wrong to think that these claims count against AA. What AA offers is a way of distinguishing a particular sort of silencing, not an explanation of whatever background conditions make it possible, let alone an account of what makes it bad (harmful, wrong) tout court. Bauer thinks it is not 'illuminating' to point out that the coffee-ordering speaker fails to achieve uptake. But whether something is illuminating depends on what one needs to shed light on. If one wants to know what distinguishes the kind of silencing suffered by this speaker from the kind suffered by that speaker, then uptake-failure is not 'beside the point' but illuminating: it tells us that this speaker, unlike that speaker, is silenced in that she is rendered unable to perform the illocutionary acts she is trying to perform. Bauer thinks 'what goes wrong' in silencing cases is the absence of human exchange. But that phrase is ambiguous between, roughly, what proximally causes the harm and what fundamentally characterizes the harm. Bauer is interested in the latter, but AA claims only to speak to the former, so these positions are perfectly consistent with each other. What proximally causes the harm is what distinguishes the form of silencing at issue: that the speaker fails to secure audience uptake. What fundamentally characterizes the harm lies deeper: it may be, as Bauer insists it is, the absence of elements crucial to human exchange. And the advocate of AA is both free and able to endorse this. ${ }^{11}$

So these objections do not oblige us to reject AA. But they do focus the attention on what is unclear about the analysis. Fricker and Maitra are right to prompt closer examination of what AA offers: is it meant to be a purely communicative conception of silencing or not? And Bauer is right to prompt closer examination of what AA requires: is it true or not that uptake is necessary for performing the acts in question? In pursuing these issues, we shall revise AA and modify its conclusion, but strengthen the argument in its support.

\section{Revising the Austinian Analysis}

A purely communicative conception is attractive for two reasons. First, it is consistent with a common view about Austin's uptake claim: that it operates

11 Though this further question does get us into complex and fascinating issues, as we have found in pursuing Fricker's objection: i.e. in at least one sense of 'human exchange', this kind of silencing is usually predicated on a peculiarly rich form of it. I don't think this need ultimately count against Bauer's worry that there may nevertheless be something crucial missing here, but it does oblige us to be more precise in specifying what that something is. 
as a requirement on communication (e.g. Bach and Harnish 1979, p. 13). ${ }^{12}$ And second, as a requirement on communication, the uptake claim is hard to resist. Herbert Clark is evidently frustrated that anyone might try (Clark 1996, pp. 137-9; see also his 1982; 2004), and we can appreciate why. For 'communication' is a certain sort of success term, one that marks a joint achievement. Just to count as communicative, an act would require something of both speaker and hearer. And, plausibly, it would require at least this of the hearer: that they recognise the force of the speaker's utterance (Searle 1969, p. 47; Strawson 1971). Unless you understood that I was issuing a warning, I could not be said to have communicated a warning to you. That is an essential part of the joint achievement which communication represents. ${ }^{13}$ So if we agree with Fricker that AA offers a purely communicative conception of silencing, we could resolve the tensions that prompt Bauer's demand for a closer examination of Austin's uptake claim: that claim will now seem neither too strong nor too significant.

But just as there are two good reasons to adopt the purely communicative conception, there are two good reasons to resist it; and they are if anything stronger. One reason has to do with AA itself: that it would not then be what it claims to be: a conception of silencing. For the fact that I am rendered unable to communicate does not show, of itself, that I have been silenced. Suppose I issue a warning but you fail to take me seriously and thus fail to grasp that it is indeed a warning. Then you will not act in the appropriate way, and we may all suffer. I have been tragically ineffectual, no doubt, but there is nothing to show I have been silenced. If I was able to issue the warning, I was able to perform the speech act I tried to perform. The fact that I was unable to get you to appreciate the speech acts I do perform is another matter. A purely communicative conception would have much to say about how a speaker would be ineffectual before an audience that fails to take

\footnotetext{
12 They represent Austin's view on uptake as follows: 'successful communication in performing an illocutionary act consists in uptake, that is, in the hearer identifying the illocutionary act being performed' (1979, p. 130). But Austin did not think success consisted in uptake; he thought success required it. There is a danger here and elsewhere of misinterpreting the uptake claim as a sufficiency claim (evident for example in Bauer's criticism of Hornsby; 2015, p. 101), one that Austin did not make and was right to avoid, even for the specific case of communication.

13 This view, which underlies the treatment of communicative action in Habermas (1984, pp. 273-337), also underlies the views of those Habermas is directly representing: not so much Austin as Searle (1969). Butler is critical in ways that she recognizes are directly relevant to Langton (1997, pp. 86-8).
} 
them seriously. But it would be an analysis of a speaker's impotence, not of their silencing. ${ }^{14}$

A second reason to resist a purely communicative conception has to do with what is at stake in AA. What matters most to Langton is freedom of speech (Langton 2009, 25-63; esp. pp. 60-3). ${ }^{15}$ But the fact that I am rendered unable to communicate does not show, of itself, that I have been denied free speech. That freedom may give me the right to express myself in certain ways. But to communicate requires that I have an audience, that they listen to me or read me carefully, that they exert themselves to understand me, and so on. And freedom of speech does not give me a right to these things.

These particular problems disappear if we adopt the alternative conception instead, conceiving of AA as a straightforward illocutionary analysis of silencing. On this conception, what fails in situations where speakers are not taken seriously is that they fail to perform their illocutionary acts. That they are thus unable to communicate follows, but is not the root of the problem. So this conception can genuinely claim to be an analysis of silencing; for someone disabled in this way is indeed silenced. And this conception puts free speech at stake; for it is the right to express oneself in certain ways that is being undermined. If what AA shows is that speakers are rendered unable to perform the illocutionary acts they try to perform, and we agree with Langton that 'free speech is a good thing because it enables people to act, enables people to do things with words: argue, protest, question, answer' (Langton 2009, p. 61), then we can appeal to AA to justify curtailing activities that render speakers unable to perform such acts. Or at least we can neutralise the standard liberal counter-argument, that curtailing such activities would undermine freedom of speech.

But there is a significant drawback to the straightforward illocutionary conception. It pays a steep price for the license to count as a genuine conception of silencing and to put free speech at stake. The advocate must defend a correspondingly stronger version of Austin's uptake claim. On this version, audience uptake is necessary simply to perform illocutionary acts,

${ }^{14}$ Consider the woman who says 'There is a wolf coming'. It is one thing to say that, not being taken seriously, she is unable to communicate that she is issuing a warning. But the claim stimulating our inquiry has been much stronger: that, not being taken seriously, she is incapable of even issuing that warning. Someone in that condition may justly be described as 'silenced', despite being able to say what she means, gathering an audience together, and having effects on that audience.

${ }^{15} \mathrm{My}$ focus here remains 'what should we regard AA as offering?' Langton herself may have moved to a communicative, possibly purely communicative, conception, though her formulations are guarded (e.g. 'what is hoped for is a certain capacity to perform communicative illocutions' Langton 2009 p. 73). 
not simply to communicate them. ${ }^{16}$ I could not be said to warn unless an audience recognised the force of my utterance, i.e. unless it understood that I was indeed issuing a warning. And this reawakens the most significant of Bauer's concerns: that AA relies on too strong a claim about uptake. For some agree with William Alston, who vigorously rejected the uptake claim, urging that no illocutionary act needs uptake to be performed (Alston 2000, pp. 24; 67). ${ }^{17}$

Alston's argument is based on appeal to two examples: 'telling you that the dean is coming to dinner' and 'asking you to bring me a towel'. I can succeed at the corresponding illocutionary acts, he insists, whether or not you even heard me, let alone understood the force of my utterances (2000, p. 24). But even if he is right about this, two problem cases are evidently not sufficient to show that no illocutionary act requires uptake. And it is not clear that Alston is right about this, given what is peculiar to his cases: that they . are essentially addressee-involving ('telling-you that $\mathrm{p}^{\prime}$, 'asking-you to $\mathrm{V}$ '). If we contrast these cases with another pair-merely saying that the dean is coming to dinner; merely asking for a towel-it becomes clear why we might well regard Alston's utterances as failing in the absence of the addressee's uptake. I could have said that the dean is coming to dinner, asked for a towel, whether or not you even heard me; but I would not then have told you that the dean is coming to dinner, asked you for a towel. What is peculiar about Alston's cases is that the individuation of the corresponding illocutionary acts - and hence their criteria of success - seem dependent on the active involvement of the person addressed. ${ }^{18}$ Telling you could not be the particular illocutionary act it is unless securing the addressee's uptake were indeed required for its performance. On being told that you had not heard, or had not understood, there would be something bizarre about my continuing to insist 'Well, I did tell you!' Retreating somewhat would be the natural step on discovering how things stand: 'Well I did try to tell you'. And this advertises one's sense that, not having secured your understanding, I have not actually told you. The same goes for asking you.

${ }^{16}$ Langton has sometimes expressed her view in ways that are consistent with this interpretation; for example, in a chapter written jointly with Jennifer Hornsby: 'Uptake consists in the speaker's being taken to be performing the very illocutionary act which, in being so taken, she (the speaker) is performing' (Langton 2009 p. 78).

${ }^{17}$ See also Bird (2002, pp. 1-15) and Jacobson (1995, pp. 64-79). For contrary views, see Warnock (1989, p. 127) Forgoson (1973, pp. 160-85) and Graham (1977, p. 91).

${ }^{18}$ Not because of some general communication requirement. For discussion of related issues about the second person, see Kukla and Lance (2009, pp. 15377). 
But there are simpler cases that get around this problem and to which an opponent of the uptake claim, like Alston, could just as easily appeal. If I utter a sentence like 'I describe myself as a socialist', I need have no audience to perform the illocutionary act it names, let alone one that understands the force with which I utter it. The same holds for sentences like 'I accept that I am partly responsible' or 'I consent to being taxed' or 'I blame capitalism for this mess' or 'I curse this government and all who work for it'. ${ }^{19} \mathrm{I}$ am not claiming that such sentences are immune to performance failure-i.e. that in uttering them, one could not fail to perform the illocutionary act they name, no matter what the circumstances. But given that they require no audience, it seems wholly implausible to suggest that this might be the reason for failure on any occasion: that no audience recognizes the force of the utterance.

Austin himself was guarded about the uptake claim, and we can now appreciate why he was right to be. He says that the claim is 'generally' in operation and that, without uptake, the illocutionary act would 'not have been happily, successfully performed' (Austin 1975, p. 116). ${ }^{20}$ 'Generally' might mean 'universally', but there is at least equal reason to think Austin simply meant 'commonly'. And the second phrase strongly indicates that he had not made up his mind on the issue. For Austin uses 'not happily performed' as a term of art, to denote acts that are open to criticism but are nevertheless performed (his general name for such compromised successes is 'abuses'; Austin 1975, Ch. 2) 21, whereas his 'not successfully performed' pulls

${ }^{19}$ I focus on explicit cases for simplicity, but the same is true of cases where the force is implicit, e.g. replacing the first example with 'I am a socialist'. Complications I set aside include those raised by Millikan (1998) to which Strawson (1998) replies.

${ }^{20}$ Austin's guarded phrasing is usually ignored, and he tends to be assigned a very strong version of the uptake claim, in accord with Strawson's interpretation of him (Strawson 1964, pp. 158-63): that no illocutionary act is performed without uptake; that the audience whose uptake is secured must be the 'intended' audience, the audience 'addressed'; that understanding the force of a locution is a matter of understanding a feature of the actual use of a sentence on a particular occasion; and that uptake must be achieved by the speaker's knowing and intentional involvement. It is surely not coincidental that ascribing Austin these strong claims makes it easier to weld his account of illocutionary acts to a Gricean account of non-natural meaning (see Bach and Harnish, passim); the possibility of such attunement is something Maitra seems to overlook in contrasting Austinian versions of AA with her proposed Gricean version (2009, pp. 309-38).

${ }^{21}$ So Alston could agree: if I ask you to bring me a towel and you do not grasp that I am asking you for anything, there is evidently something 'unhappy' 
in the opposite direction: that the acts in question are not performed at all (his general name for such unequivocal failures is 'misfires'; Austin 1975, Ch 3). ${ }^{22}$

My own view is that we have yet to appreciate the complexities here. ${ }^{23}$ Austin's successors lost his guardedness and have tended to think that the uptake claim is either just obviously true for all illocutionary acts, or just as obviously false of any of them. The fact that the debate survives on a tiny diet of examples - a feature bequeathed by Austin - helps explain this. ${ }^{24}$ We need to open our inquiry to the full range of illocutionary acts. It would be wrong to anticipate the full results of such an investigation, but even an initial survey makes it overwhelmingly plausible that the uptake claim is not general. Some illocutionary acts require the active participation of an audience and some do not.

We have already seen examples of those that do not. In examples of those that do, it may be participation of the addressee that is crucial to performance of the illocutionary act. 'I entreat you to think again', or 'I thank you for your gift' are examples. Plausibly, I will not have entreated or thanked at all in uttering these sentences, even if we have an audience who grasps what I am about, unless you, my addressee, have grasped that I am entreating and thanking. Suppose you do not hear me but we are overheard. It seems reasonable to reflect as follows in such circumstances: 'I did say "I entreat you to think again", with the intention of thereby entreating N. N. to reconsider, but I wonder whether I actually did entreat N. N., for it seems that although many heard me, she did not; or if she did hear me, that she did not understand my words; or if she did understand my words, that she nevertheless, and for whatever reason, did not grasp that I was entreating her'. ${ }^{25}$

These cases contrast with others where the uptake claim holds, because participation of an audience is required, but that audience need only take the

about the act I have nevertheless performed; you will not do for me what performing the act tried to get you to do.

${ }^{22}$ Alston could not agree, even if Austin just meant 'commonly', for his position is that the performance of illocutionary acts is never dependent on uptake.

${ }^{23}$ In the next paragraphs, I deepen one aspect of my (2011) analysis of the uptake claim and set other aspects aside.

24 Thus Austin discusses warning alone (1975, pp. 116-7), Strawson adds only bequeathing (1971, p. 158.) and Alston restricts himself to 'telling you that' and 'asking you to' (2000, p. 24).

${ }^{25}$ Promising fits this category; its 'relational structure', as David Owens puts it, requires that the addressee accept the speaker's promise $(2012,219)$, which entails, minimally, that the addressee understand the force of the speaker's utterance. 
form of a witness rather than an addressee. For example, if I say 'I concede defeat in this election' while addressing you (my opponent), it is plausible to require that someone recognise I am indeed conceding, for performance of the act named, but that 'someone' need not be you, deafened as you may be by the adulation of your supporters; a witness will do. Again, if I say 'I adjourn this meeting', I need an audience to recognise the force of my utterance. But if those I am addressing are still too heatedly in debate even to hear me, I may nevertheless succeed in adjourning the debate if the secretary witnessing and recording proceedings understands that this is what I have done in my utterance. (We can imagine circumstances in which it is important to know whether an act occurred during the meeting or after it was adjourned, where the weight placed on this witness's testimony is testimony to the truth of this conclusion. $)^{26}$

This distinction between uptake-dependent and uptake-free illocutionary acts cuts across the standard ways of classifying such acts. Appealing just to the cases I have discussed, the class of Expositives (Assertives) contains the uptake-dependent 'concede' and the uptake-free 'describe'; Commissives contains the dependent 'bet' and the free 'accept'; Directives contains the dependent 'entreat you' and the free 'consent'; Exercitives (Declaratives) contains the dependent 'adjourn' and the free 'curse'; and Behabitives (Expressives) contains the dependent 'thank you' and the free 'blame'.

The distinction also cuts across standard attempts to characterise illocutionary acts in terms of their special intentional properties, as in the theory of Bach and Harnish (1979) which develops ideas of Grice (1989, pp. 213-223). They regard describing, accepting and consenting as requiring uptake by virtue of being 'communicative' illocutionary acts (1979, pp. 13; 17; 70; 151). But utterances naming such acts may be uptake-free, as we have seen. Conversely, Bach and Harnish regard conceding, betting and adjourning as 'conventional' illocutionary acts, where the uptake claim is not meant to apply, since they are not 'communicative' acts (1979, pp. 108-19). But utterances naming such acts may be uptake-dependent, as we have seen.

And finally, the distinction cuts across standard attempts to characterise illocutionary acts in terms of their special normative properties, as in the theory of Kukla and Lance (2009) which develops ideas of Brandom (1994, pp. 3-66). They would regard 'entreat you' and 'thank you' as requiring uptake by virtue of being essentially second personal illocutionary acts (2009,

\footnotetext{
${ }^{26}$ 'I bet you all the money I have that Labour will lose' is, arguably, different again. Undoubtedly performance of the illocutionary act named requires the uptake of an audience, but what is required may well be the uptake of an addressee (unlike my examples of 'concede' and 'adjourn') and the uptake of a witness (unlike my examples of 'entreat' and 'thank').
} 
pp. 153-77), and this seems right, for the independent reasons that I gave in response to Alston's cases: that they require the active participation of an addressee. But conceding and adjourning are also uptake-dependent, as we have seen, and yet for reasons that Kukla and Lance do not admit, since conceding and adjourning do not require the active participation of an addressee (a witness suffices), and hence there is nothing essentially second personal about these acts. ${ }^{27}$

In summary, we face a choice. It will help specify it to recall the basic features of AA: that there is a particular form of silencing in which (a) speakers are taken as non-serious by their audience, and thus (b) fail to secure their audience's uptake, where (c) uptake is a necessary condition on performing illocutionary acts, so that (d) they are unable to perform the illocutionary acts they try to perform, and thus (e) should be considered as silenced.

One option is to regard AA as offering a purely communicative analysis, where we revise (c) to $\left(\mathrm{c}^{*}\right)$ uptake is a necessary condition on performing communicative acts, and $(\mathrm{d})$ to $\left(\mathrm{d}^{*}\right)$ they are unable to perform the communicative acts they try to perform. Now $\left(\mathrm{c}^{*}\right)$ may be overwhelmingly plausible, but (e) no longer follows. This is no longer an analysis of any sort of silencing. And we can no longer appeal to this analysis as part of a free speech argument.

The alternative option is to retain AA as a straightforward illocutionary analysis. (e) follows from (a)-(d); this is indeed an analysis of a particular sort of silencing. And (e) is a sufficiently strong conclusion; we can appeal to AA as part of an effective free speech argument, e.g. to curtail activities that are responsible for situation (a). But there is a problem with this option: (c) and (d) are false.

There is a revised form of this illocutionary option, based around the closest true claims to $(\mathrm{c})$ and $(\mathrm{d})$, namely $\left(\mathrm{c}^{* *}\right)$ uptake is a necessary condition on performing some ('uptake-dependent') illocutionary acts; and ( $\left.\mathrm{d}^{* *}\right)$ speakers are unable to perform the uptake-dependent illocutionary acts they try

${ }^{27}$ To say this, we need not deny that such speech acts 'essentially place agents in normative relationships structured by the claims we make upon one another' (2009, p. 177). It is just that there need be nothing essentially second personal about an illocutionary act for it to place agents in this way. Kukla and Lance argue that, without invoking an addressee (what they call speaking to another as 'you') or securing their active participation, my attempts to perform illocutionary acts would treat others as mere 'normative-statustrading-engines' (2009, p. 177). But conceding and adjourning are counterexamples: I can perform them without speaking to another as 'you', but also without denying the agential status of those concerned-because I depend on the agential participation of a (third person) witness to my act. 
to perform. But this version of the argument delivers something much more modest in relation to speakers who are taken as non-serious by their audience: i.e. $\left(\mathrm{e}^{* *}\right)$ they should be considered as silenced with respect to the uptake-dependent illocutionary acts they try to perform.

This revised form of the illocutionary option - call it revised AA - is certainly an analysis of a particular sort of silencing, so it is preferable to the purely communicative alternative. Perhaps $\left(\mathrm{e}^{* *}\right)$ is not strong enough to form part of an effective free speech argument, e.g. to curtail activities that are responsible for situation (a). But that is a substantial further issue, for another occasion. What I shall briefly demonstrate here, in the final section, is that revised AA can still shed light on difficult and complex cases.

\section{Uptake and Poetry}

Austin is notorious, at least in literary circles, for encouraging us to treat speakers of poetic utterances - 'poets' for shor ${ }^{28}$-as non-serious. ${ }^{29}$ Frege and others had said similar things. ${ }^{30}$ But Austin was particularly thorough, seemingly intent on leaving no possible respect in which an audience might take any poetic utterance as serious.

Poetry is a 'use of language' which is "'not serious"' (Austin 1975, p. 104); in poetry, 'language is... used not seriously' (Austin 1975, p. 22); if an utterance occurs in a poem it 'figures in a context not wholly "serious"' (Austin 1971, p. 15); in poetry, 'the words' are not 'spoken "seriously"' (Austin 1975, p. 9); in poetry, 'the words' are not spoken 'so as to be taken "seriously"' (Austin 1975, p. 9); if we 'issue an utterance of any kind whatsoever' in 'writing a poem', 'it would not be seriously meant' (Austin 1979, p. 241); if we 'issue an utterance of any kind whatsoever' in 'writing a poem', 'we shall not be able to say that we seriously performed the act concerned' (Austin 1979, p. 241); 'If the poet says "Go and catch a falling star" or whatever it may be, he doesn't seriously issue an order' (Austin 1979, p. 241).

Literary critics sometimes claim that such attitudes are rife, at least amongst analytic philosophers, and that Austin is partly to blame. We might deny this, but it would also be interesting to ask what would follow if they

${ }_{28}^{28}$ The abbreviation is merely for convenience, and it is safe since nothing here turns on the point, but of course poets are rarely to be taken straightforwardly as the speakers of their poetic utterances.

${ }^{29}$ Austin's remarks are complex, and the responses to them by philosophers and literary critics even more so; I discuss them fully elsewhere (see de Gaynesford 2009b; 2011b; 2013; 2017). The points I make here, in applying revised AA to these remarks, are original to this paper.

${ }^{30}$ Frege claimed that poetry is not fit for many of the tasks of language, like assertion, on the grounds that 'the necessary seriousness is lacking' (der dazu nötige Ernst fehlt) (Frege 1977, p. 8). 
were right. Suppose then that (a) of AA applies: poets are taken as nonserious by their audience, partly because of Austin's remarks. Should we conclude from this that poets are silenced, and that Austin is partly to blame?

Consider cases in which it is clear that a speaker is attempting to perform an illocutionary act in their poetic utterance, and it is clear what act they are trying to perform, because they make it explicit. Chaucer tries to dedicate his poem Troilus and Criseyde in saying

O moral Gower, this book I direct

To thee and to thee, philosophical Strode (Chaucer 2008, p. 585) Shakespeare's speaker tries to concede a point in Sonnet 130 in saying

I grant I never saw a goddess go;

My mistress when she walks treads on the ground (Shakespeare 2002, p. 641)

Geoffrey Hill's speaker tries to ask a question in his The Triumph of Time in saying

So-Croker, MacSikker, O'Shem - I ask you:

what are poems for? (Hill 1998, p. 82)

Revised AA tells us that, since we are supposing (a) applies, these speakers will fail to secure their audience's uptake (i.e. (b)). But it also tells us that only some illocutionary acts are dependent on securing that uptake; namely, those that are 'uptake-dependent' (i.e. $\left(\mathrm{c}^{* *}\right)$ ). And this illuminates the situation by distinguishing between our cases.

Thus Chaucer's 'I direct' (i.e. dedicate) may be regarded as uptakedependent. But this is not because dedicating requires the active participation of an addressee (one can dedicate a book to a dead person). It is because dedicating is a particular kind of act, one whose performance plausibly requires a witness. Geoffrey Hill's 'I ask you' may also be regarded as requiring uptake, but in this case because it requires the active participation of an addressee. This is for reasons that we have discussed above, which make ask you an essentially second personal illocutionary act. Shakespeare's 'I grant' (i.e. I concede), on the other hand, is neither witness- nor addresseedependent but uptake-free. It is an illocutionary act that one may perform without any audience at all, let alone an audience that understands the force of one's utterance. Alone of these examples, then, this illocutionary act is performed regardless of Austin's remarks and their effects.

In short, there is a category of cases where (for the best of reasons perhaps) Austin's remarks nevertheless threaten to silence poets-some poets, and on some occasions. And revised AA gives us the means with which to appreciate this fact with clarity and precision.

There is one final related matter on which revised AA sheds light. Suppose we focus not on poetic utterance but on Austin's utterances about poetry: should we take him as non-serious? There would certainly be good grounds, given the notable levity that characterizes his remarks on poetry (see 
de Gaynesford 2009b; 2011b). Suppose then that Austin is in fact serious but his audience takes him not to be, so that (a) of AA applies. Should we conclude from this that Austin is silenced in his remarks on poetry?

Revised AA tells us that Austin would then fail to secure his audience's uptake. But his remarks on poetry are uttered with the force of assertion, which is not uptake-dependent. One may successfully assert what one likes, without an audience, let alone their understanding that one is asserting anything. So Austin is not silenced even if we regard him as nonserious in his remarks on poetry. He performs these illocutionary acts, regardless of our attitudes. And it is revised AA which explains why. ${ }^{31}$

\section{Bibliography}

Alston, William P. 2000. Illocutionary Acts and Sentence Meaning Ithaca: Cornell University Press

Austin, J. L. 1971 ‘Performative-Constative' in John Searle (ed) The Philosophy of Language Oxford University Press, pp. 13-22.

Austin, J. L. 1975 How To Do Things With Words $2^{\text {nd }}$ edition Urmson, J. O. and Sbisà, Marina (eds) Oxford University Press

Austin, J. L. 1979 'Performative utterances' in his Philosophical Papers, ed. J. O Urmson and G. J. Warnock, $3^{\text {rd }}$ edition Oxford University Press, pp. 233-52.

Bach, Kent and Harnish, Robert 1979. Linguistic Communication and Speech Acts London: MIT Press.

Bauer, Nancy 2015. How To Do Things With Pornography Harvard University Press.

Bird, Alexander. 2002 'Illocutionary silencing' Pacific Philosophical Quarterly 83, pp. 1-15.

Brandom, Robert. 1994 Making It Explicit Harvard University Press

Butler, Judith. 1997 Excitable Speech: A Politics of the Performative London:

Routledge

Chaucer, Geoffrey 2008. Troilus and Criseyde $3^{\text {rd }}$ edition Larry D. Benson (ed.)

Oxford University Press.

Clark, Herbert H. and Carlson, Thomas B. 1982 'Speech act and hearers' beliefs' in Pragmatics: A Reader 1991 Steven Davis (ed) Oxford University Press pp. $177-98$

Clark, Herbert H. 1996. Using Language Cambridge University Press.

Clark, Herbert H. 2004 'Pragmatics of language performance' in The Handbook of Pragmatics ed. Laurence R. Horn and Gregory Ward Oxford: Blackwell pp. 365-82.

${ }^{31}$ I am particularly grateful to Savas Tzohatzidis for encouraging me to be more explicit about the implications of revising the uptake claim. I thank audiences at the SOPHA conference in Montreal (June 2015) and at Reading for helpful criticism. 
Forgoson, L. W. 1973 'Locutionary and illocutionary acts' in Isaiah Berlin et al Essays on J. L. Austin Oxford University Press pp. 160-85

Frege, Gottlob. 1977 'Thoughts' in Logical Investigations, P. T. Geach (ed.) New Haven: Yale University Press, pp. 1-30.

Fricker, Miranda 2007. Epistemic Injustice Oxford University Press.

Gaynesford, M. 2009a 'Illocutionary acts, subordination and silencing', Analysis, 69, 488-90

Gaynesford, M. 2009b 'Incense and Insensibility: Austin on the 'nonseriousness' of Poetry' Ratio, 22, pp. 464-85.

Gaynesford, M. de 2011a. 'Speech, action and uptake', in Agents and Their Actions M. de Gaynesford (ed) Oxford: Blackwell pp. 121-37

Gaynesford, M. de 2011b 'How Not To Do Things With Words', The British Journal of Aesthetics, 51, pp. 31-49

Gaynesford, M. de 2013. 'Speech acts, responsibility and commitment in poetry' in Peter Robinson (ed) The Oxford Handbook of Contemporary British and Irish Poetry Oxford University Press.

Gaynesford, M. de 2017. The Rift in the Lute: Attuning Poetry and Philosophy

Oxford University Press, Forthcoming.

Graham, Keith 1977 J. L. Austin Sussex: Harvester Press

Grice, Paul 1989. Studies in the Way of Words Harvard University Press

Gustafsson, Martin 2011. 'Introduction' in Gustafsson, Martin and Sørli,

Richard The Philosophy of J. L. Austin Oxford University Press pp. 1-31.

Habermas, Jürgen 1984 The Theory of Communicative Action: Volume One tr.

Thomas McCarthy Boston: Beacon Press.

Hill, Geoffrey 1998. The Triumph of Love New York: Houghton Mifflin

Company.

Hornsby, Jennifer 1994 'Illocution and its significance' in Tsohatzidis (ed) pp.

pp. 187-207.

Jacobson, Daniel 'Freedom of speech acts? A response to Langton' Philosophy and Public Affairs 24, pp. 64-79

Kukla, Rebecca and Lance 2009. Mark Yo! And Lo! The Pragmatic Topography of the Space of Reasons Harvard University Press.

Langton, Rae 2009. Sexual Solipsism: Philosophical Essays on Pornography and

Objectification Oxford University Press

MacKinnon, Catharine 1987 Feminism Unmodified: Discourses on Life and Law Harvard University Press.

Maitra, Ishani 2009. 'Silencing speech' Canadian Journal of Philosophy, 39, pp. 309-38.

Maitra, Ishani 2012 'Subordinating speech' in Ishani Maitra and Mary Kate McGowan (eds) Speech and Harm: Controversies over Free Speech Oxford University Press pp. 95-118

Mikkola, M 2008 'Contexts and pornography' Analysis 68, pp. 316-20. 
Millikan, Ruth Garrett 1998. 'Proper function and convention n speech acts' in The Philosophy of P. F. Strawson ed. L. E. Hahn Illinois: Open Court. pp. 25-43 Owens, David 2012. Shaping the Normative Landscape Oxford University Press Ricks, Christopher 1996. 'Austin's Swink' in his Essays in Appreciation Oxford University Press.

Rilke, Rainer Maria 1987. 'Duino Elegies: The First Elegy' in The Selected Poetry of Rainer Maria Rilke tr. Stephen Mitchell London: Picador, 1987, pp. 150-5. Saul, J. 2006. 'Pornography, speech acts and context' Proceedings of the Aristotelian Society 106, pp. 229-48

Searle, John 1969. Speech Acts Cambridge University Press

Shakespeare, William 2002 The Oxford Shakespeare: Complete Sonnets and Poems Colin Burrow (ed.) Oxford University Press.

Strawson, P. F. 1964 'Intention and convention in speech acts' in his LogicoLinguistic Papers 1971 London: Methuen pp. 149-69.

Strawson, P. F. 1998 'Reply to Ruth Garrett Millikan' in The Philosophy of P. F. Strawson ed. L. E. Hahn Illinois: Open Court. pp. 44-8.

Tsohatzidis, Savas L. (ed.) 1994. Foundations of Speech Act Theory: Philosophical and Linguistic Perspectives London: Routledge

Waldron, Jeremy 2012. The Harm in Hate Speech Harvard University Press. Warnock, G. J. 1989 J. L. Austin London: Routledge. 